\title{
meso-Substituted Dipyrromethanes from Vinylogous Aromatic Heterocycles and Their Utilization to the Synthesis of meso-Functionalized Porphyrins
}

\author{
Seong-Jin Hong, Mi-Hye Lee, and Chang-Hee Lee* \\ Institute of Basic Science and Deparment of (hemistry, Kanguon National University. Chum-Chon 260)-701, Korea \\ Received July 3, 20044
}

\begin{abstract}
$m{ }^{\prime} s o$-Functionalized dipyrromethanes 6-10 were synthesized by acid-catalyzed addition of pyrrole to $\alpha$ position of 2-alkenyl pyrroles. The regiochemistry of the reaction can be explained by either the formation of more stable carbocation intermediate or $\beta$-addition of $\alpha, \beta$-unsaturated carbonyl compounds. The starting 2 alkenyl pyrroles were synthesized by Aldol condensation of 2 -formylpyrrole with active methylene compounds such as nitromethane, diethylmalonate and malononitrile. Attempted ' $2+2$ ' condensation of meso-diethylmalonyldipyrromethane, $m k^{\prime} s o$ - ( $p$-tolyl)dipyrromethane and $p$-tolualdehyde afforded three different porphyrins 12. 13 and 14 in reasonable yields. On the other hand. meso-(nitromethyl)dipyrromethane with $p$-( $t$ butyl)benzaldehyde resulted in the formation of three different porphyrins such as 5.15-dicyano-10.20diarylporphyrin (16), 5-cyano-15-formyl-10.20-diarylporphyrin (17) and 5.15-diformyl-10.20-diarylporphyrin (18) in low yields. Conversion of nitromethyl groups to nitrile and (or) formyl group was observed under the porphyrin forming conditions.
\end{abstract}

Key Words : meso-(Diethylmalonyl)-dipyrromethancs, Vinylpyroles, 5, 15-Dicyano-10.20-diarylporphyrin. 5-Cyano-15-formyl-10.20-diarylporphyrin

\section{Introduction}

The meso-substituted potplyyins have been widely used as key crmponents in constructing porphyrin-based model systems and the design olten requires incorporation of different substituents around the periphery of the mother macrocycles. The synthesis of asymmetrically subsituted porphyrins at meso-positions is still challenging lask due to the dificulties arising from separation and limited availability of suitable building blocks. A number of dillerent synthelie routes have been developed to achieve this goal so far. ${ }^{1-4}$. Most of the reported methods generally adopted acidcatalyzed condensation of meso-aryl dipyrromethanes with aldehydes in order to obtain asymmetrically substituted porplyyrins." We also reported that meso-substituted porphyrins can be synthesized by oxidative coupling of pentapyrrolic oligomers followed by treatment with acid. ${ }^{6}$ Dircclly attached functional groups at the meso-position enable the construction of supramolecular architectures based on the noncovalent or covalent interactions. Thus, it is worthwhile to develop novel synthetic methods of meso-functionalized porphyrins.

In this article, we describe a new synthetic method of dipyrromethanes starting from vinyl substituted aromatic heterocycles including pyrrole, thiophene and furan. Also reported is the synthesis of porphyrinic macrocycles utilizing synthesized dipyrromethanes and unusual conversion of nitromethyl group to cyano or formyl group.

\section{Experimental Section}

Prolon NMR spectra (400 MH\%, Bruker DPX-400) were

Corresponding Author. e-mail: chblec(akangwon.ac.kr recorded using TMS as the internal standard. Iligh and Low resolution FAB mass spectra were obtained on AUTO SPEC M-363 high-resolution mass spectrometer. Column chromalography was performed over silica gel (Merck, 230-400 mesh). Pyrrole was distilled al atmospherie pressure from $\mathrm{CaII}_{2}$. Both $\mathrm{CII}_{2} \mathrm{Cl}_{2}$ and $\mathrm{CICl}_{3}$ (reagent grade) were distilled from $\mathrm{K}_{2} \mathrm{C}^{\circ} \mathrm{O}_{3}$ to eliminate traces of acid. All other reagents were oblained from Aldrich and used as received unless noted olherwise.

2-(Dicyanoethen-1-yl)pyrrole (1). Pyrrole-2-carboxaldehyde (1.0 g, 10.5 mmol), NaOAc (0.88 g, $10.5 \mathrm{mmol})$. methylamine hydrochloride $(0.71 \mathrm{~g}, 10.5 \mathrm{mmol})$ and malononitrile $(0.66 \mathrm{~mL}, 10.5 \mathrm{mmol})$ were dissolved in methanol $(20 \mathrm{~mL})$. The mixture was stirred for $2 \mathrm{hr}$ at $25^{\circ} \mathrm{C}$ and then was combined with brine $(20 \mathrm{~mL})$ and water $(30$ $\mathrm{mL}$ ). The mixture was extracted with methylene chloride $(20 \mathrm{~mL} \times 3)$ and the organic layer was dried over anhydrous $\mathrm{Na}_{2} \mathrm{SO}_{4}$. Solvent was removed in va'uo and the remaining solid was purified by column chromatography on silica $\left(\mathrm{CH}_{2} \mathrm{Cl}_{2}\right)$. The yellow compound was again recrystalized from hexanes/ethyl acetate. Yield: $1.43 \mathrm{~g}(95 \%)$; mp 127 $128^{\circ} \mathrm{C}:$ ' 'II NMR (CDCl 3 ) $\delta 6.50-6.48(\mathrm{~m}, 1 \mathrm{II}$, pyrrole-H), $6.98(\mathrm{~m}, \mathrm{lH}$, pyrrole-H), $7.3(\mathrm{~m}, \mathrm{lH}$, pyrrole- $\mathrm{H}), 7.5(\mathrm{~s}, 1 \mathrm{H}$, pyrrole-H), 9.75 (br s, $1 \mathrm{H}$, pyrrole-H).

2-(Diethoxycarbonylethen-1-yl)pyrrole (2). Pyrrole-2carboxaldehyde ( $2 \mathrm{~g}, 21 \mathrm{mmol}$ ), sodium acetate ( $1.76 \mathrm{~g}, 20.9$ mmol), methylamine hydrochloride ( $1.42 \mathrm{~g}, 21 \mathrm{mmol}$ ) and diethylmalonate $(3.19 \mathrm{~mL}, 21 \mathrm{mmol})$ were treated identically as for the synthesis of 1 . Yield $4.9 \mathrm{~g}(98 \%)$, oil: ${ }^{1} \mathrm{II}$ NMR $\left(\mathrm{CDCl}_{3}\right) \delta 1.26-1.36\left(\mathrm{~m}, 6 \mathrm{H}, \mathrm{CH}_{3}\right), 4.25-4.35(\mathrm{~m}, 4 \mathrm{H}$, $\left.\mathrm{CH}_{2}\right), 6.31-6.33$ (m, 1II, pyrrole-JI), 6.31-6.33 (m, 1HI, pyrrole-H), $7.08(\mathrm{~m}, 1 \mathrm{H}$, pyrrole-H), $7.67(\mathrm{~s}, 1 \mathrm{H}$, vinyl-H).

2-(2-trans-Xitrovinyl)pyrrole (3) ${ }^{7}$. Pyrrole-2-carboxalde- 
hyde (1.773 g, $18.6 \mathrm{mmol})$, sodium acelate (1.538 $\mathrm{g}, 18.8$ mmol), methylamine hydrochloride (1.261 g, $18.7 \mathrm{mmol})$ and nitromethane (20 mL, $369.3 \mathrm{mmole)}$ were treated identically as for the synthesis of 1 . Yield: $1.97 \mathrm{~g}(76 \%)$; mp $111-113^{\circ} \mathrm{C}$; ' II NMR (CDCl $) \$ 6.39-6.41$ (m, 1II, pyrroleII), 6.80-6.81 (m, 1JI, pyrrolc-IJ), 7.10-7.11 (m, 1H, pyrroleII), $7.40(\mathrm{~d}, J=13.4 \mathrm{IJ} /, 1 \mathrm{IJ}$, vinyl-JI). 7.95 (d, $J=13.4 \mathrm{H} /$. 1II, vinyl-II).

2-(2-frans-Nitrovinyl)furan (4). Futtural (2 mL, 24.1 mmol), sodium acetate (1.998 g. $24.4 \mathrm{mmol}$ ), methylamine hydrochloride (1.629 g. $24.1 \mathrm{mmol})$ and nitromethane (20 $\mathrm{mL}, 369.3 \mathrm{mmol}$ ) were treated identically as for the synthesis of 1. Yicld: $3.30 \mathrm{~g}(98 \%)$; m $73-74^{\mathrm{g}} \mathrm{C}$; ${ }^{1} \mathrm{II}$ NMR $(\mathrm{CDCl}, 3) \& 6.58(\mathrm{q}, 1 \mathrm{IJ}$, Jutan-JI), 6.89 (d, $J=3.5 \mathrm{IJ} /, 1 \mathrm{H}$, furan-JI), $7.53(\mathrm{~d}, J=13.3 \mathrm{II} \%, 1 \mathrm{IJ}$, vinyl-II), 7.59-7.60 (m, $1 \mathrm{II}$, furan-IJ), 7.78 (d, $J=13.3 \mathrm{JI} \%, 1 \mathrm{IJ}$, vinyl-IJ).

2-(2-trans-Nitrovinyl)thiophene (5). 2-Thiophene catboxaldehyde (1 $\mathrm{mL}, 10.7 \mathrm{mmol})$, sodium acelate (0.889 g, $10.8 \mathrm{mmol}$ ), melhylamine hydrochloride (1.261 g, 10.7 $\mathrm{mmol}$ ) and nitromethanc (23 mL, $424.7 \mathrm{mmol})$ were 1 realed identically as for the synthesis of 1 . Yield: $1.38 \mathrm{~g}(83 \%) ; \mathrm{mp}$ $78-79^{\circ} \mathrm{C} ;{ }^{1} \mathrm{JI}$ N.MR (CDCI$) \& 7.14-7.16(\mathrm{~m}, 1 \mathrm{II}$, 1hiophencII), 7.45-7.46 (m, 1II, thiophenc-IJ), 7.48 (d, $J=13.4 \mathrm{II} \%$. III, vinyl-JI), 7.57 (d, $J=5.0 \mathrm{II} \%, 1 \mathrm{II}$, thiophenc-IJ), 8.15 (d, $J=13.4$ IJ $\%$ 1II, vinyl-JI).

5-(2-Diethylmalonyl)dipyrromethane (6). To the solution of 2 (0.88 g, $3.4 \mathrm{~mm} v \mathrm{l})$ and pyitole $(9.4 \mathrm{~mL})$ was added 1rilluoroacetic acid $(1.3 \mathrm{~mL}, 5$ equiv.). The mixlure was stitred for 2.5 hr at $25^{\circ} \mathrm{C}$. Then aqueous $\mathrm{NaOIJ}$ solution $(0.1$ $\mathrm{N}, 5 \mathrm{~mL}$ ) and water (30 mL) were added in order to quench the reaction and the mixture was extracted wilh $\mathrm{CCI}_{2} \mathrm{Cl}_{2}(20$ $\mathrm{mL} \times 3)$. The organic layer was dried $\left(\mathrm{Na}_{2} \mathrm{SO}_{4}\right)$ and solvent was removed in vacto. Remaining dark solid was purilied by column chromatography on silica $\left(\mathrm{CJI}_{2} \mathrm{Cl} \mathrm{I}_{2}\right)$. Yicld: $0.2 \mathrm{~g}$ (20\%); mp 126-1.30 ${ }^{\circ} \mathrm{C}:{ }^{l}$ II N.MR (CDCI $) \delta 1.17-1.14(\mathrm{~m}$,

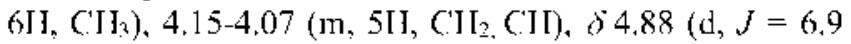
IJ\%, 2JI, vinyl-JI), 5.96-5.97 (dd, $J=2.9,5.9$ IJ $\%$ 2II, pyrrole-H), 4.57 (q. $J-2.9 \mathrm{~Hz}, 2 \mathrm{H}$, pyrrole-H), 6.67-6.68 (m, 2H, pyrrole-H), 8.72 (br s, $1 \mathrm{H}, \mathrm{NH}$ ).

5-(Nitromethyl)dipyrromethane (7). The mixture of 3 (0.588 g, $4.04 \mathrm{mmol}$ ), indium(III) chloride (0.091 g. 0.411 minol) and pyrrole ( $10 \mathrm{~mL}, 144.1 \mathrm{mmol}$ ) was stirred for $4 \mathrm{hr}$ at $25^{\circ} \mathrm{C}$. Then the mixture was combined wilh water $(5 \mathrm{~mL})$ and brine $(20 \mathrm{~mL})$. The mixture was extracted with $\mathrm{CH}_{2} \mathrm{Cl}_{2}$ $(30 \mathrm{~mL} \times 3)$ and the organic layer was dried. Solvent was removed in vacuo and the resulting dark blue oil was purified by column chromatography on silica $\left(\mathrm{CH}_{2} \mathrm{Cl}_{2} /\right.$ EtOAc - 95/5). Yield: $0.5 \mathrm{~g}(60 \%) ;{ }^{1} \mathrm{~J}$ I NMR (C.DCI $\left.\mathrm{I}_{3}\right) \delta 4.83$ (d, $J-7.6 \mathrm{~Hz}, 2 \mathrm{H},\left(\mathrm{CH}_{2}\right), 5.01(1, J=7.6 \mathrm{II} \%, 1 \mathrm{II}$, meso-II), 6.10 (s, 2H, pyrrole-H), 6.17-6.19 (m, 2H, pyrrole-H), 6.70$6.72(\mathrm{~m}, 2 \mathrm{H}$, pyrrole-H) 7.98 (br s, $2 \mathrm{H}, \mathrm{NH})$.

5-(Nitromethyl)-10-oxadipyrromethane (8). The mixture of 4 (0.51 g. $3.64 \mathrm{mmol})$, indium(III) chloride (0.081 g. $0.366 \mathrm{mmol})$ and pyrrole $(6 \mathrm{~mL}, 84.0 \mathrm{mmol})$ was stirred for $2 \mathrm{hr}$ at room temperature. Then water $(5 \mathrm{~mL})$ was added and the organic layer was dried in vacuo. The resulting yellow viscous oil was separated by column chromalography on silica $\left(\mathrm{C}_{2} \mathrm{I}_{2} \mathrm{C} \mathrm{l}_{2} / \mathrm{I}\right.$ Iexanes $\left.=9 / 1\right)$. Yield: $0.2 \mathrm{~g}(27 \%) ;{ }^{1} \mathrm{II}$ NMR $\left(\mathrm{CDCl}_{3}\right) \delta 4.77-4.93$ (m, 2II, CHI), $4.95(1, J=7.6 \mathrm{II} \%, 1 \mathrm{H}$, meso-H), 6.08-6.10 (m, 1II, pyrroleH), $6.16(\mathrm{dd}, J=2.9,5.9 \mathrm{II} \%, 1 \mathrm{H}$, pyrrole-H), 6.19 (d, $J=3.2$ H/., 1II, furan-II), 6.32-6.34 (m, 1HI, Juran-II), 6.71-6.74 (m, 1II, pyrrole-H), 7.39-7.40 (m, 1II, furan-II), 8.24 (bs, 1II, NH).

5-(Nitromethyl)-10-thiadipyrromethane (9). Compound 5 (0.21 g. $1.33 \mathrm{mmol})$, indium(III) chloride (0.031 g, 0.14 mmol) and pyrrole (4 mL, $57.65 \mathrm{mmol}$ ) was treated identically as for the synthesis of 8 . Column chromatography on silica $\left(\mathrm{CII}_{2} \mathrm{Cl}_{2}\right)$. Yicld: $0.093 \mathrm{~g}(32 \%)$; ${ }^{l} \mathrm{I}$ NMR (CDCI $\delta 4.79-4.95\left(\mathrm{~m}, 2 \mathrm{II}, \mathrm{CII}_{2}\right), 5.19(1, J=7.8 \mathrm{II} /, 1 \mathrm{II}$, meso-H $)$, 6.10 (s, 1II, pyrrole-HI), 6.15-6.17 (m, 1II, pyrrole-HI), 6.696.70 (m, 1II, pyrrole-HI), 6.92-6.93 (m. 1II, thiophenc-HI): 6.95-6.97 (m, 1II, thiophene-HI), 7.23-7.25 (m, 1II, thiophene-II), 8.01 (bs, 1H, NII).

2-[Bis-(pyrrol-2-yl)-methyl]pyrrole (10). To the mixture of 1 (0.09 g. $0.62 \mathrm{mmol})$ and pyrrole $(2 \mathrm{~mL}, 30.8 \mathrm{mmol})$ was added TFA (241 $\mu \mathrm{L}, 3.13$ mmol). The mixlure was heated for $5 \mathrm{hr}$ at $60^{\circ} \mathrm{C}$. and then the reaction was quenched by addition ol aqueous $\mathrm{NaOH}(0.1 \mathrm{~N}, 30 \mathrm{~mL})$. The mixture was extracted with $\mathrm{CH}_{2} \mathrm{CC}_{2}(30 \mathrm{~mL} \times 3)$ and the organic layer was dricd $\left(\mathrm{Na}_{2} \mathrm{SO}_{4}\right)$. Solvent was removed in racko and the remaining solid was purified by column chromatography on silica (EiOAc/I Iexanes = 1/1). Yield: $0.067 \mathrm{~g}(51 \%) ; \mathrm{mp}$ 133-134 ${ }^{\circ} \mathrm{C}:{ }^{1}$ II NMR (CDCl 3 ) $\delta 5.56$ (s, 1 II, meso-H J), 6.06 $(\mathrm{m}, 3 \mathrm{II}$, pyrtolc-II), 6.18 (q, 3II, $J=3.0 \mathrm{II} \%$, pyrolc-H $)$, 6.69-6.70 (m, 3JI, pyrrole-H). 7.98 (br s, 3H, NII); EI MS calcd for $\mathrm{C}_{13} \mathrm{II}_{13} \mathrm{~N}_{3} 211.11$. Found 211.12 .

5,15-Bis(diethylmalonyl)-10,20-di(p-tolyl)porphyrin (12) and 5-Diethylmalonyl-10,15,20-tri(p-tolyl)porphyrin (13) and $5,10,15,20$-Tetra(p-tolyl)porphyrin (14). Compound 6 $(0.1 \mathrm{~g}, 0.33 \mathrm{mmol}), 5$-(p-tolyl)dipyrromelhane (78 mg: 0.33 mmol), $p$-tolualdehyde (77 $\mu \mathrm{L}, 0.66 \mathrm{mmol})$ were dissolved in $\mathrm{CJ}_{2} \mathrm{Cl}_{2}(33 \mathrm{~mL})$ with stiming and then $\mathrm{BF}_{3}(\mathrm{OEt})(42 \mathrm{~mL}$. $0.33 \mathrm{mmol}$ ) was added. The whole mixlure was stirred for $40 \mathrm{~min}$ at $0^{\circ} \mathrm{C}$ and $\mathrm{DDQ}(0.22 \mathrm{~g}, 0.999 \mathrm{mmol})$ was added. The mixture was stirred for $1 \mathrm{lr}$ and was combined with water. The mixture was extracted with $\mathrm{CH}_{2} \mathrm{Cl}_{2}(30 \mathrm{~mL} \times 3)$ and the organic layer was dried $\left(\mathrm{Na}_{2} \mathrm{SO}_{4}\right)$. Solvent was removed in racto and the remaining solid was separated by column elromatography on silica $\left(\mathrm{CH}_{2} \mathrm{Cl}_{2}\right)$. Three diflerent products 12, 13 and 14 were isolated. Spectroscopic data for (12); Yield: $16 \mathrm{mg}(12 \%)$; ${ }^{1} \mathrm{I}$ NMR (CDCl $\left.\mathrm{l}_{3}\right) \delta-2.7$ (s. 2JI, $\mathrm{NH}), 1.13\left(\mathrm{t}, J-7.1 \mathrm{~Hz}, 12 \mathrm{H}, \mathrm{CH}_{3}\right), 2.72\left(\mathrm{~s}, 6 \mathrm{II}\right.$, tolyl-CH $\left.\mathrm{I}_{3}\right)$, $4.25-4.3\left(\mathrm{~m}, 8 \mathrm{H}_{1} \mathrm{CH}_{2}\right), 7.26(\mathrm{~s}, 2 \mathrm{II}, \mathrm{CIJ}), 7.55$ (d, $J=7.7 \mathrm{II} \%$ $4 \mathrm{H}, \beta$-pyrrole), 8.04 (d, $J-7.8 \mathrm{~Hz}, 4 \mathrm{H}, \beta$-pyrrole), 8.9 (d, $J$ $-4.9 \mathrm{~Hz}, 4 \mathrm{H}, \mathrm{Ar}-\mathrm{H}), 9.47$ (d, $J-5.0 \mathrm{~Hz}, 4 \mathrm{H}, \mathrm{Ar}-\mathrm{H}) ;{ }^{13} \mathrm{C}$ NMR $\left(\mathrm{CDCl}_{3}\right) \delta 13.97,21.54,57.98,62.24,76.69,77.01$, $77.21,77.33,109.58,120.43,127.31,128.59,132.56$, $134.25,137.54,139.33,169.96 ;$ FAB-MS clacd for $\mathrm{C}_{48} \mathrm{~J} \mathrm{I}_{46} \mathrm{~N}_{4} \mathrm{O}_{8} 806.33$, found 807.3 (MII ). For (13); Yicld: 60 mg $(25 \%) ;{ }^{1}$ II NMR (CDCl $) \delta-2.73$ (s, 2II, NII), $1.14(\mathrm{I}, J$ $\left.-7.1 \mathrm{~Hz}, 6 \mathrm{H}, \mathrm{CH}_{3}\right), 2.7$ (s, 6H, tolyl-CJI $), 4.29$ (m, 4II, $\left.\mathrm{CH}_{2}\right), 7.3$ (s, 1II, CII), 7.55 (d, $\left.J=7.8 \mathrm{H} \%, 6 \mathrm{II}, \mathrm{Ar}-\mathrm{II}\right), 8.07$ $(\mathrm{d}, J-7.8 \mathrm{~Hz}, 6 \mathrm{H}$, Ar-H), 8.81 (q, $J-4.8 \mathrm{~Hz}, 4 \mathrm{H}, \beta$ 
pyrrole), $8.94(\mathrm{~d}, J=5.0 \mathrm{~Hz}, 2 \mathrm{H}, \beta$-pyrrole), $9.5(\mathrm{~d}, J=5.0$ $\mathrm{ll} z, 2 \mathrm{H}, \beta$-pyrrole); ''C NMR (CDClis) $\delta 13.98,21.50$, $21.53,58.15,62.19,76.69,77.00,77.21,77.32,108.38$, $120.28,121.29,127.34,127.48,128.49,129.67,131.04$, $132.42,134.41,134.46,137.41,138.84,139.32$; FAB-MS clacd for $\mathrm{C}_{4} \mathrm{H}_{42} \mathrm{~N}_{4} \mathrm{O}_{4} 738.32$, found $739.2\left(\mathrm{MH}^{\prime}\right)$. For (14); Yicld: $17 \mathrm{mg}$ ( $15 \%$ ); 'H NMR (CDC.13) $\delta-2.8$ (s, 2H. NH), 2.7 (s, 6] I, 1olyl-CH3), 7.55 (d, $J=7.79 \mathrm{~Hz}, 4 \mathrm{H}, \beta$-pyrrole), $8.09(\mathrm{~d}, J=7.85 \mathrm{~Hz}, 4 \mathrm{H}, \beta$-pyrtole), 8.85 ( $\mathrm{s}, 4 \mathrm{Il}, \Lambda \mathrm{r}-\mathrm{H})$.

10,20-Di(4-tert-butylphenyl)-5,15-dicyanoporphyrin (16), 10,20-Di(4-tert-butylphenyl)-5-cyano-15-formylporphyrin (17) and 10,20-Di(p-tert-butylphenyl)-5,15diformylporphyrin (18). Compound $7(0.18 \mathrm{~g}, 0.88 \mathrm{mmol})$, 4-tert-butylbenzaldehyde ( $50 \mu \mathrm{L}, 0.9 \mathrm{mmol}), \mathrm{NI}{ }_{4} \mathrm{Cl}(0.49$ g, 9.2 mmol) were dissolved in $\mathrm{CII}_{3} \mathrm{CN}(88 \mathrm{~mL})$ and $\mathrm{BF}_{3} \cdot(\mathrm{OEt})_{2}(22 \mu \mathrm{L}, 0.17 \mathrm{mmol})$ was added with stirring at 0 ${ }^{\prime} \mathrm{C}$. The solution was stirred for $30 \mathrm{~min}$ and then triethyl amine $(24, L \mathrm{~L}, 0.17 \mathrm{mmol})$ and DDQ $(0.649 \mathrm{~g}, 2.9 \mathrm{mmol})$ were added successively and stirred for $1 \mathrm{hr}$. The reacion mixture was combined with water $(50 \mathrm{~mL})$ and extracted with $\mathrm{CII}_{2} \mathrm{Cl}_{2}$ (50 $\left.\mathrm{mL} \times 3\right)$. The organic layer was dried $\left(\mathrm{Na}_{2} \mathrm{SO}_{4}\right)$ and solvent was removed in vac'wo. Remaining solid was separated by column chromatography on silica $\left(\mathrm{CH}_{2} \mathrm{Cl}_{2} /\right.$ hexanes $\left.=2 / 1\right)$. Three porphyrin components were isolated and characterized. (16) Yicld: $3 \mathrm{mg}(1 \%)$; ${ }^{\prime} \mathrm{H}$ NMR $\left(\mathrm{CDCl}_{3}\right) \delta-2.69(\mathrm{~s}, 2 \mathrm{H}, \mathrm{NH}), 1.64(\mathrm{~s}, 18 \mathrm{H}$, tert-butyl-H), 7.85 (d, $J=8.0$ H I $\angle, 4 \mathrm{I}$ I, $\Lambda \mathrm{r}-\mathrm{I} \mathrm{l}), 8.12(\mathrm{~d}, J=8.0 \mathrm{Il} \angle, 4 \mathrm{II}, \wedge \mathrm{r}-\mathrm{II}), 9.10$ (d, $J=4.8 \mathrm{I}[z, 4 \mathrm{I}$, pyrrole-l I) 9.66 (d, $J=4.8 \mathrm{I}[z, 4 \mathrm{I}$, pyroleH); IR (CN): 2217; UV-V1s. (CII $\left.\mathrm{Cl}_{2}\right) \hat{\lambda}_{\text {max }}(\varepsilon)$ : 421 (87714), 523 (3305), 563 (5333), 605 (1019), 66I (4362); FAB MS Calcd. for $\mathrm{C}_{42} \mathrm{H}_{36} \mathrm{~N}_{6}$ (624.30), Found (625.1) ( $\left.\mathrm{MH}^{\prime}\right)$; (17) Yicld: $4 \mathrm{mg}(\mathrm{l} \%)$; ${ }^{1} \mathrm{H}$ NMR (CDCl 3$) \delta-2.59$ (s, 2H, NH), 1.64 (s, I8I 1, tert-bulyl-]I), 7.83 (d, $J=8.2 \mathrm{IIz}, 4 \mathrm{II}, \wedge \mathrm{r}-[\mathrm{I}), 8.1 \mathrm{I}(\mathrm{d}, J$ $=8.2 \mathrm{I}[z, 4 \mathrm{I}, \Lambda \mathrm{r}-\mathrm{I}), 9.03(\mathrm{~d}, J=4.5 \mathrm{II} z, 2 \mathrm{H}$, pyrole-H $), 9.09$ (d, $J=4.8 \mathrm{I}[z, 2 \mathrm{I}$, pyrrole-l I), 9.60 (d, $J=4.8 \mathrm{I}[\mathrm{z}, 2 \mathrm{I}$, pyroleII), 10.04 (br s, 2l I, pyrrolc-[1), 12.60 (s, 1II, Cl IO); IR (CN): 2217, (CIJO): L674; UV-Vis. ( $\left.\mathrm{CH}_{2} \mathrm{Cl}_{2}\right) \hat{\Lambda}_{\text {mux }}(\varepsilon): 423$ (94271), 528 (2902), 573 (579l), 671 (4585); FAB MS Calcd. for $\mathrm{C}_{42} \mathrm{II}_{37} \mathrm{~N}_{5} \mathrm{O}$ (627.30), Found (628.20) (MH'); 'H NMR (CDCl - TFA- $d$ ) $\delta 1.66(\mathrm{~s}, 18 \mathrm{II}$, tert-butyl-H), 8.10 (d, $J=8.0 \mathrm{II} z, 4 \mathrm{H}$, $\Lambda \mathrm{r}-\mathrm{I} 1), 8.40(\mathrm{~d}, J=8.0 \mathrm{I}[\mathrm{z}, 4 \mathrm{I} \mathrm{I}, \Lambda \mathrm{r}-\mathrm{II}), 8.77$ (d, $J=4.9 \mathrm{II} z, 2 \mathrm{H}$, pyrrole-I $), 8.92(\mathrm{~d}, J=4.8 \mathrm{~Hz}, 2 \mathrm{H}$, pyrrole-I $), 9.53(\mathrm{~d}, J=4.8$ II $2,2 \mathrm{H}$, pyrrole-II), 9.67 (d, $J=4.9 \mathrm{H} z, 2 \mathrm{I}$, pyrrole-I I), 12.39 (s, III, CHO); (18) Yield: $11 \mathrm{mg}(4 \%)$; ${ }^{1} \mathrm{H}$ NMR $\left(\mathrm{CDCl}_{3}\right) \delta$ -2.43 (s, 2lI, NII), 1.64 (s, I8H, tert-butyl-II), 7.80 (d, $J=8.2$ II $\angle, 4 \mathrm{II}, \Lambda \mathrm{r}-\mathrm{Il}), 8.07$ (d, $J=8.2 \mathrm{H} \angle, 4 \mathrm{II}, \Lambda \mathrm{r}-\mathrm{II}), 8.98(\mathrm{~d}, J=4.9$ II $2,4 \mathrm{H}$, pyrrolc-H), 9.95 (d, $J=4.9 \mathrm{Il} z, 4 \mathrm{I} \mathrm{I}$, pyrrole-H), 12.48

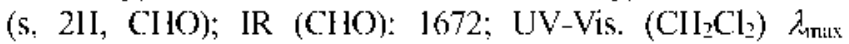
$\left(\varepsilon \times 10^{4}\right): 427(14.97), 539(0.33), 585(1.26), 684(1.12) ;{ }^{13} \mathrm{C}$ NMR: $31.679,35.009,110.957,123.896,124.060,129.181$,
$134.289,138.232,151.382,194.949 ;$ FAB MS Calcd. for $\mathrm{C}_{42} \mathrm{H}_{38} \mathrm{~N}_{4} \mathrm{O}_{2} 630.30$, Found $631.30\left(\mathrm{MH}^{\prime}\right)$.

\section{Results and Discussion}

The synthesis of dipyrromethane from vinyl pyrroles has been reported previously. ${ }^{8}$ However, the reported methods generally adopted multi-substituted pyrroles, strongly acidic reaction conditions and elevated temperature. Our approaches, on the other hand, are milder and versatile to acess various dipyrroemthane analogues bearing any combination of pytroles, furans and thiophenes. Aldol reaction of 2formylpymole with active methylene compounds such as malononitrile or ethyl cyanoacetate has been well documented" and in some cases, the alkenyl pyrroles have been applied as a protecting group for 2-fomylpyrole duc to their relative stability in acidic media. On the other hand, acid-catalyzed condensation of alkenyl pyrroles with pyrtole has not been studied well to the best of our knowledge. Attempted Aldoltype reaction of 2-formylpyrrole, 2-fornylfuran or 2-formyl thiophene with active methylene compounds gave corresponding 2-alkenyl derivatives in high yiclds as shown in Scheme 1. Typical reaction was treatment of 2-formylpytrole and malononitrile with sodium acelate/methylammonium chloride in methanol.

Since pyrroles have been recognized as a C-nucleophile ${ }^{10}$ in some cases, we attempted to synthesize dipyrromethanes by nucleophilic addition of pyrrole to the alkenylpyrrole derivatives as shown in Scheme 2. For preliminary sludies, we directed our atention to the synthesis of simple 2(nitrovinyl)pyrrole. When 2-formylpyrrole was treated with nitromethane in the presence of sodium acetate at room temperature, trans-2-(nitrovinyl)pyrrole 3 was formed in $76 \%$ yield. The reaction gave even higher yields of corresponding vinyl derivatives 4 or 5 , when 2-furfural or 2formylthiophene were treated under the same conditions. Inspired by these results, we examined the reaction with malononitrile or dicthyl malonate with 2-formylpyrrole and observed the formation of corresponding alkenylpyrroles 1 and 2 in $95 \%$ and $98 \%$ yiclds, respectively.

Desired dipyrromethane derivatives then were prepared by condensation of the 2-alkenylpyrroles with pyrrole in neat cxcess pyrrole presence (Scheme 2). These results were comparable with conventional methods such as pyrrolealdehyde condensation and 2-( $\alpha$-hydroxymethyl)pyrrolepyrrole condensation. "

Several different acids including $\mathrm{TFA}, \mathrm{BF}_{3}, \mathrm{TiCl}_{4}, \mathrm{ZnCl}_{2}$, $\mathrm{InCl}_{3}$, and $p$-TS $\Lambda$ were examined in order to optimize the reactions. When 3 or 5 were treated with catalytic amount of trifluoroacelic acid in neat excess pyrrole, only trace amount
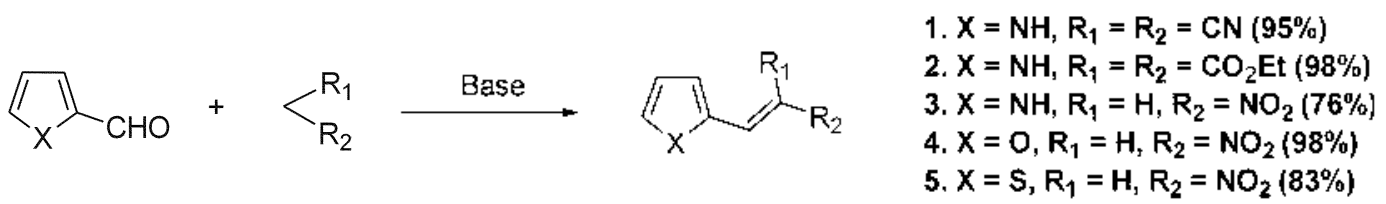

Scheme 1 
<smiles>[R]C([R])=Cc1[X]ccc1</smiles><smiles>CCOC(C)C(C)(F)F</smiles>

2- 5<smiles>N#CC(C#N)=Cc1ccc[nH]1</smiles>

1<smiles></smiles><smiles>c1c[nH]c(C(c2ccc[nH]2)c2ccc[nH]2)c1</smiles>

6. $X=\mathrm{NH}, \mathrm{R}_{\mathbf{1}}=\mathrm{R}_{\mathbf{2}}=\mathrm{CO}_{2} \mathrm{Et}(20 \%)$

7. $X=N H, R_{1}=H, R_{2}=N_{2}(60 \%)$

8. $X=O, R_{1}=H, R_{2}=N_{2}(27 \%)$

9. $X=S, R_{1}=H, R_{2}=N_{2}(32 \%)$

$10(51 \%)$

Scheme 2

of the desired product was isolated. On the other hand, applying $\mathrm{InC} \mathrm{I}_{3}$ as catalyst afforded good yield of the desired products in both cases. Eeven better yiclds (82-84\%) were achieved when the pyrrolic nitrogen was protected with $t$ Boc or benzene sulfonyl group in the case of 3 . Similar addition of pyrrole to the electron delicient olelins in the presence of $\mathrm{InCl}_{3}$ has been reported previously. ${ }^{\text {? }}$ Interestingly, the condensation of 1 with pyrrole affored only 1ripyrylmethane 10 in $51 \%$ yicld. The formation of 10 could be explained by rapid elimination of malononitrile group from the initially formed dipyrromethane followed by nucleophilic attack of pyrtole to the resulting $2,2^{\prime}-$ dipyrrylmethyl cationic intermediate. ${ }^{13}$ The methylene protons in compound 8 and 9 are diastercotopic in nature and clean separation of signals were observed in proton NMR spectra.

Since various dipyrromethanes are in hand, we attempted 10 synthesize porphyrins by ' 212 ' condensation as shown in Scheme 3. The condensation of dipyrromethanes 6, 11 with $p$-1olualdehyde in the presence of $\mathrm{BF}_{3}(\mathrm{OEt})_{2}$ as standard manner ${ }^{14}$ afforded three different porphyrins 12, 13 and 14 in $12 \%, 25 \%$ and $15 \%$ yiclds, respectively. The resonance line of the $\alpha$-protons on the meso-positions in 12 and $\mathbf{1 3}$ appeared at $7.30 \mathrm{ppm}$ as sharp singlet indicating strong influence of the diamagnetic ring current.

On the other hand, porphyrin forming reaction of dipyrromethane 7 with $p$-(t-butyl)benzaldehyde 15 unexpectedly gave three different porphyrins 16, 17 and 18 in $1 \%, 1 \%$ and 4\% yields, respectively, as shown in Scheme 4. However, desired porphyrin 19 was not isolated. We examined various oxidants and acid catalysts in order to isolate porphytin 19 , but isolated porphyrin components were porphyrin 16, 17, and 18 with similar yields as those shown in Scheme 4 . The fomation of porphyrin products was nol influenced by change of solvent or reaction temperature. Oxidative conversion of nitromethyl group to formyl or carboxyl group has been documented as Nef reaction. ${ }^{15}$ This partial oxidative conversion can be explained by considering a nucleophilic attack of water to the carbon center of the oxime $(-\mathrm{C}=\mathrm{N}-)$ or nitrile oxide (-CNO) intemediate. But conversion of nitromethyl group to cyano group is rather unusual especially in acidic condition.

Nlthough the formation of porphyrin 16 is not casy to explain mechanistically at this point, the inherent clectronrich nature of the porphyrin ring might play crucial role in forcing dehydration of oxime-intemediate instead of nucleophilic atlack of water. The reaction is useful for direct access to the meso-cyano substituted porphyrins in spite of<smiles>CCOC(=O)C(C(=O)OCC)C(c1ccc[nH]1)c1ccc[nH]1</smiles>

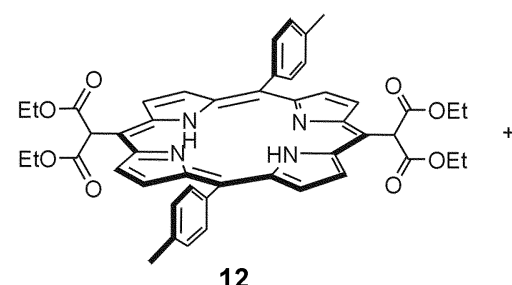

12

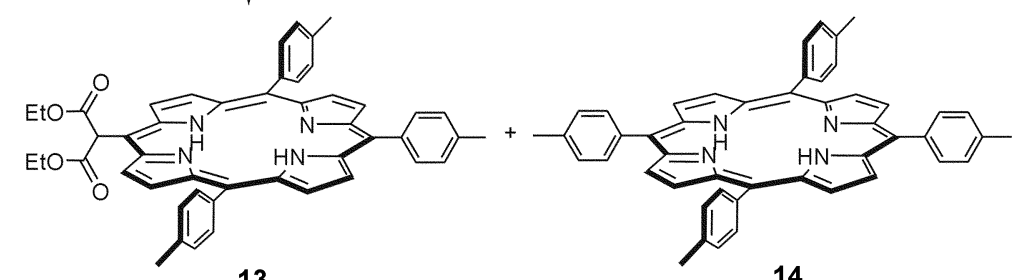

13
14

Scheme 3 


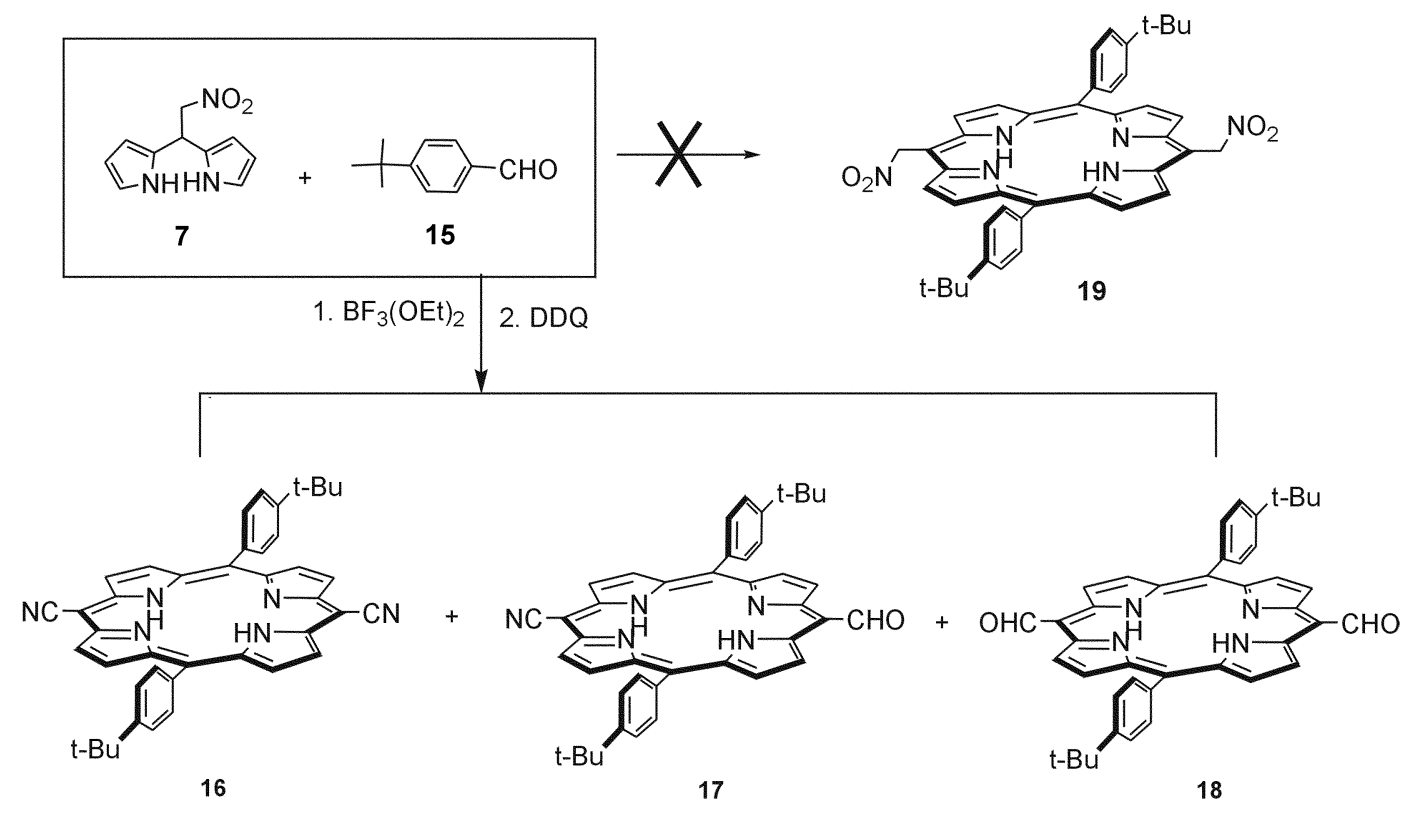

Scheme 4

lower overall yields of porphyrins.

All the spectroscopic data were well matched with the proposed structures. For example, porphyrin 16 and 17 showed typical vibrational absorption at $2217 \mathrm{~cm}$ ' indicating the existence of $-\mathrm{CN}$ group. Porphyrin 17 showed both typical carbonyl stretching at $1674 \mathrm{~cm}$ ' and $-\mathrm{CN}$ stretching vibration including typical C.HI stretching vibration of aldehyde. The combined resonance lines of 16 and those of 18 were well matched with the resonance lines of porphyrin 17. This observation indicates the independent nature of the meso-substiluents. The UV-vis. absorption spectra taken in methylene chloride displayed quite different $Q_{x}(0,0)$ bands at $661 \mathrm{~nm}, 671 \mathrm{~nm}$ and $684 \mathrm{~nm}$ respectively, to be compared with those of the TPP $(649 \mathrm{~nm})$. The Soret band of these three porphyrins appeared at $42 \mathrm{lnm}, 423 \mathrm{~nm}$ and $427 \mathrm{~nm}$ respectively, which werc similar with that of TPP $(42 \mathrm{lnm})$. The effect of direct meso-substitution of unsalurated group

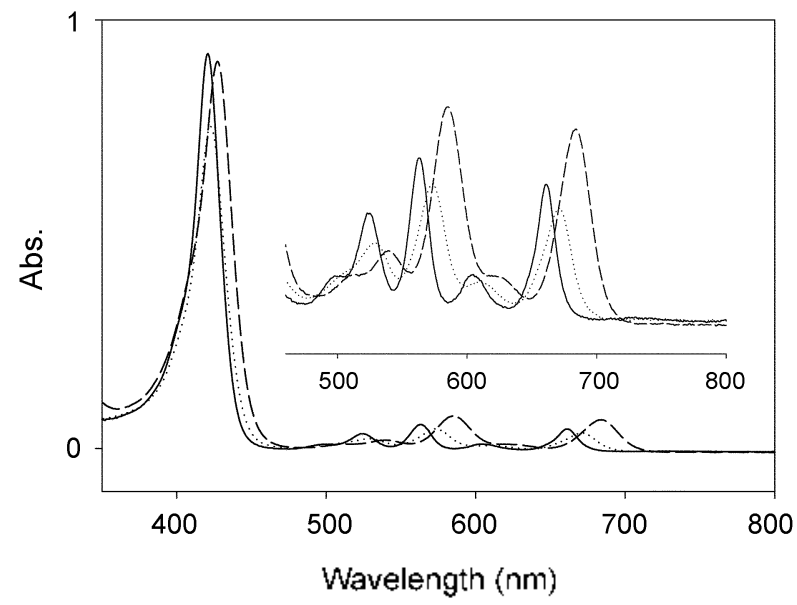

Figure 1. UV-vis spectra of porphyrin $16\left(-, 1.1 \times 10^{5} \mathrm{M}\right), 17$ $\left(\cdots \cdots, 8.0 \times 10^{-6} \mathrm{M}\right)$ and $18\left(---, 6.0 \times 10^{-6} \mathrm{M}\right)$ in $\mathrm{CH}_{2} \mathrm{C}_{2} \mathrm{l}_{2}$. conjugated with overall macrocyclic $\pi$-system on spectral properties usually shifted the Q-bands to longer wavelength. The enhanced absorption at longest wavelength of porphytins 16,17 and 18, was typical trend in the porphyrins bearing electron-withdrawing substituents diametrically at mesoposition. ${ }^{\text {lt }}$ The meso-formyl substituents somewhat interact with porphyrin $\pi$-system more efliciently compared with those of cyano-substituent.

In conclusion, we have demonstrated a useful synthesis of meso-substituted dipyrromethanes with good yiclds under mild conditions. The synthesized dipyrromethanes could be good building blocks for the convenient access to the mesofunctionalized porphyrins. The porphyrin systems synthesized with these studies will provide variety of access to the family of direc meso-functionalized porphyrins.

Acknowledgement. This work was supported by a grant (KRF-99-005-D00042) from the basic science research program of the Korea Research Foundation. The Institute of Basic Science and the Vaseular System Research Center (VSRC) a1 KNU is acknowledged for support.

\section{References}

1. Lindsey, J. S. In The Ponphwin Handhook: Kadish. K. M., Smith, K. M.. Guilard, R., Eds. Academic press: San Diego, CA. 2000: Vol. 1, pp 45-118.

2. Lindsey, J. S. The Synhesis of Meso-Sutwstituted Pomphyrins in Metalloponphyin-Cataflzed Oxidatons; Montanari, F; Casclla, L., Eds.: Kluwer Academic Publishers: The Netherlands, 1994: pp $49-86$.

3. Lindsey, J. S.; MacCrum, K. A.; Tyhonas, J. S.; Chuang. Y.-Y. J. Org. Chem. 1994, 59, 579-587.

4. Lindsey, J. S.; Wagner, R. W. J. Org. Chen. 1989, 54, 828-836.

5. Rao, P. D.; I.ittler, B. J.; Geier III, G. R.: I.indscy, J. S. J. Org. Chem. 2000, 65, 1084-1092.

6. Ka, J. W.; Lee, C. H. Tetrahedron Lett. 2001, 42, 4527-4529. 
7. Strachan, J. P.; O'Shea, D. F.; Balasubramanian. T.; Lindsey, J. S. J. Org. Chem. 2000, 65, 3160-3172.

8. (a) Bum, D. II.; Smith, K. M. J. Chem. Res. (S) 1990, 178-179. (b) Paine III, J. B.; Dolphin, D. J. Org. Chem, 1988, 53, 2787-2795. (c) Wijesekera, I. I'; Paine III, J. B.; Dolphin, D. J. Org. Chem. $1985,51), 3832-3838$.

9. (a) Paine III, I. B.; Woodward, R. B.; Dolphin, D. J. Org. Chem. 1976, 41, 2826-2835. (b) Settambolo, R.; Laz7aroni. R.; Messeri, T.; Mazzetti, M.; Salvadori, P. J. Org. Chem. 1993, $58,7899-$ 7902.

10. Vicente, M. G. H.; Snith, K. M. $J$. Org. Chem. 1991. 56, 44074418 .

11. (a) Lee, C. I1.; Lindsey, J. S. Tetrahedrm 1994, 50, 11427-11440. (b) Littler, B. J.; Miller, M. A.; Hung, C. H.: Wagner, R. W.; O'Shea, D. F.; Boyle, P. D.: Lindsey, J. S. I. Org. Chem. 1999, 64, $1391-1396$.

12. Yadav, J. S; Abraham. S.; Subba Reddy. B. V; Sabitha, G. Tetrahedron Lett. 2001, 42, 8063-8065.

13. Kawakámi, I'; Stcuki, H. Tetraheron Let 1999. 4t, 1157-1160.

14. Rao, P. D.; Dhanalekshmi, S.; Littler, B. J.; Lindsey, J. S. I. Ong. Chem. 2000, 65, 732.3-7344.

15. (a) Matt, C.; Wagner, A.: Mioskowski, C. J. Org. Chem 1997. 6?, 234-235. (b) Pinnick, H. W. Ory. Resct. 1990, 38, 655-792. (c) Ballini. R.; Petrini. M. Tetrahedron 2004, 60. 1017-1047.

16. Nishino, N.; Wagner. R. W.; Lindsey. J. S. J. Ory. Chem. 1996. 61. 7534-7544. 